\title{
Mutậwầsith \\ JURNAL HUKUM ISLAM \\ JUAL BELI PRODUK IMITASI FASHION PERSPEKTIF UNDANG-UNDANG HAK CIPTA NOMOR 28 TAHUN 2014 DAN HUKUM ISLAM
}

\author{
Solihah Sari Rahayu, Novianti Syarifah, Muhamad Dani Somantri \\ Institut Agama Islam Latifah Mubarokiyah Tasikmalaya, Indonesia \\ Email: Solihah.sr@gmail.com
}

\begin{abstract}
Abstrak
Jual beli dalam Al-Quran disebutkan 3 bentuk yaitu: tijarah, bai', syira'. jual beli adalah pertukaran harta (mal) dengan harta dengan menggunakan cara tertentu. Pertukaran harta dengan harta disini, diartikan harta yang memiliki manfaat serta terdapat kecenderungan manusia untuk menggunakannya, cara tertentu yang dimaksud adalah sighat atau ungkapan ijab dan qabul. Pasar adalah adanya penjual dan pembeli saling bertemu, salah satu dari berbagai sistem, institusi, prosedur, hubungan sosial dan infrastruktur dimana usaha menjual barang, jasa, dan tenaga kerja untuk orangorang dengan imbalan uang. Barang dan jasa yang dijual menggunakan alat pembayaran yang sah seperti uang fiat. Kegiatan ini merupakan bagian dari perekonomian. Ini adalah pengaturan yang memungkinkan pembeli dan penjual untuk item pertukaran. Persaingan sangat penting dalam pasar, dan memisahkan pasar dari perdagangan. Penelitian ini mendepenelitiankan dan mengkaji permasalahan mengenai konsep pembajakan karya-karya di bidang hak cipta dalam perspektif hukum Islam dengan menggunakan UndangUndang Nomor 28 Tahun 2014 Tentang Hak Cipta sebagai fokus studinya. Adapun tujuan penelitian adalah untuk mengangkat tentang solusi hukum Undang-Undang tentang Hak Cipta. Dalam usaha penelitian ini, penulis menggunakan metode observasi langsung dan tidak langsung. Pembajakan dengan menyamakan hukum dari pencurian dapat menggunakan metode qiyas. Apabila dikaji berdasarkan metode qiyas, segala apapun bentuk dari pembajakan merupakan haram dan harus dijauhi. Dengan beberapa penjelasan di atas maka segala apapun bentuk pembajakan baik cara/metode maupun objek atau sasaran yang mengarah pada pembajakan hak cipta hukumnya adalah haram.

Kata Kunci: fasion, hukum Islam, imitasi, jual beli
\end{abstract}

\section{Abstract}

Buying and selling in the Qur'an is mentioned 3 forms: Tijarah, Bai ', Syira '. Buying and selling is the exchange of assets (malls) with property in certain ways. The exchange of treasures with treasures here, meaning the treasures that have benefits and there is a tendency for people to use them, a particular way is sighat or expression of ljab and Qabul. The market is the presence of sellers and buyers meet each other, one of the various systems, institutions, procedures, social relations and infrastructure where businesses sell goods, services, and labor for people in exchange for money. Goods and services are sold using legitimate payment instruments such as fiat money. This activity is part of the economy. This is a setting that allows buyers and sellers to exchange items. Competition is very important in the market, and separates the market from trading. This research describes and examines the problem of piracy of works in the field of copyright in the perspective of Islamic law by the use of Law No. 28 of 2014 on copyright as a focus of his studies. The purpose of research is to lift about legal solutions on copyright law. In this research effort, the authors use direct and indirect observation methods. Piracy by equating the law of theft can use the method Qiyas. When examined by the method of Qiyas, any form of piracy is unlawful and should be dened. With some explanation above then all forms 
Jual Beli Produk Imitasi Fashion Perspektif Undang-Undang Hak Cipta Nomor 28 Tahun 2014 Dan Hukum Islam

of piracy either way/method or object or target that leads to piracy of copyright law is unlawful.

Keywords: fasion, Islamic law, imitation, buying and selling

\section{PENDAHULUAN}

Persoalan ekonomi merupakan aspek yang fundamental, bagi semua manusia banyak cara untuk memperjualbelikan barangnya untuk mendapatkan uang untuk keperluan sehari-hari. Entah itu berjualan dengan tatap muka atau via sosmed, barang yang diperlihatkan atau diperjualbelikan tidaklah asli atau zaman sekarang menyebutkan dengan bahasa KW/Imitasi. Ada beberapa toko yang menjual barang $\mathrm{KW} /$ Imitasi tersebut tanpa sepengetahuan orang yang menjual barang aslinya, mengapa demikian, tidak hanya kebutuhan dasar atau keseharian bahkan semua itu diperluas untuk kebutuhan pelengkap seperti ponsel, tablet, kendaraan, gadget, sampai aksesoris atau perhiasan yang sering menjadi trend di kalangan anak muda saat ini.

Majelis Ulama Indonesia (MUI) telah mengeluarkan fatwa dengan No.1/Munas/VII/15/2005 tentang perlindungan hak kekayaan intelektual yang memutuskan bahwa dalam hal ini kekeayaan intelektual adalah kekayaan yang timbul dari hasil piker yang menghasilkan sebuah produk atau proses yang berguna untuk manusia dan diakui oleh negara berdasarkan peraturan perundangan-undangan yang dalam hal ini hak cipta sebagai hak eksklusif bagi seorang pencipta atau penerima hak untuk mengumumkan dan memperbanyak hasil ciptaannya atau memberikan izin kepada pihak lain melalui lisensi dengan adanya pembayaran royalti. ${ }^{1}$ Produk imitasi adalah produk tiruan atau bukan asli. ${ }^{2}$

Tiruan disini maksudnya produk yang dibuat sama persis dengan produk aslinya atau sedikit menyerupai yang bertujuan untuk mengelabui para konsumen yang tidak sadar bahwa sebenarnya barang tersebut hanyalah barang tiruan. Misalnya produk merk "LV" menjadi "BV", "Chrocodile" menjadi "Clocodile". Istilah „KW" berasal dari kata kwalitas yakni kualitas yang konotasinya berarti „tiruan". Awalnya populer di kalangan produk tas wanita (branded atau terkenal), oleh pedagang untuk memudahkan pengkategorian kwalitas dengan masing-masing kisaran harganya seperti : kwalitas (tiruan) super, kwalitas 1 atau kwalitas 2 dan seterusnya disingkat: KW Super, KW-1, KW-2. Untuk KW super berarti yang terbaik mendekati aslinya, sedangkan $\mathrm{KW}-1$ berada di peringkat bawahnya. Akhirnya meluas menjadi istilah untuk produk-produk lain dalam menyatakan kwalitas tiruannya. Produk-produk KW tersebut banyak diproduksi di Korea,Hongkong, Guangzhou China dan Amerika.

\footnotetext{
${ }^{1}$ Suryo Utomo, Tomi. Hak Kekayaan Intelektual: (Bandung: t.tp, 2006), hlm.11

2 Departemen Pendidikan Nasional, Kamus Besar Bahasa Indonesia Pusat Bahasa, (Jakarta: PT. Gramedia Pustaka Utama, 2008), hlm. 528
} 
Jual Beli Produk Imitasi Fashion Perspektif Undang-Undang Hak Cipta Nomor 28 Tahun 2014 Dan Hukum Islam

Islam menjelaskan dalam jual beli barang atau menjual produk imitasi itu adalah dosa, karena menipu pembeli dan mengambil hak cipta orang lain. Adapun produk imitasi yang tersisa, maka bisa dijual. Pada kondisi itu, calon pembeli diberitahu bahwa produk tidak asli. Jika setelah mengetahui kondisi barang yang sebenarnya, dia masih ingin membelinya, maka tidak masalah. Namun, jika produk imitasi itu dijual keluar, penjual harus menolak untuk membantu produsen menjual produk imitasi. Setiap muslim harus patuh kepada Allah dan mencari rezeki yang halal, dengan behati-hati dalam Syariat Allah dan meminta keridhaan Allah untuk mendapatkan kemudahan dari-Nya. Tertuju pada Q.S Al syu"ara ayat:183 yang berarti "Dan janganlah kamu merugikan manusia pada hak-hak nya dan janganlah kamu merajalela di muka bumi dengan membuat kerusakan". 3

Meningkatnya permintaan konsumen menuntut produsen untuk memproduksi barang memenuhi kebutuhan pelanggan, dengan kwalitas yang baik. Tapi tampaknya beberapa masalah bagi beberapa produsen yang memiliki modal terbatas, di lengkapi dengan keahlian yang tidak kalah dengan produk bermerek terkenal, membuat mereka menghasilkan barang imitasi yang mereka distribusikan di pasar atau toko. Jika kita melihat fenomena yang terjadi saat ini, sebagian besar orang membuat/menjual beli barang imitasi sebagai kebiasaan mereka dan memilikinya.

Berbisnis merupakan aktivitas niaga yang berkembang secara pesat di masyarakat. Salah satu tujuan berbisnis untuk memperoleh keuntungan serta untuk menciptakan kesejahteraan social bagi pelaku usaha maupun konsumen. Salah satu caranya yaitu melakukan usaha jual beli yang dalam pelaksanaanya berdasarkan hukum yang berlaku di masyarakat dan hukum agama yang telah diakui Negara. Halnya dalam pengamatan penyusun terhadap sejumlah praktik jual beli KW/Imitasi yang terjadi di pasar Jalan Raya Ciawi, terdapat beberapa pemilik toko aksesoris seperti tas, sepatu, pakaian, handphone, dsb. Terdapat beberapa pemilik toko yang menjual barangnya tersebut dan memanfaatkan ketidaktahuan si pembeli terhadap kualitas barang yang debelinya tersebut.

Bentuk barang sama dengan yang aslinya/bermerek, akan tetapi bahan yang membedakan antara keduanya, Jual beli tiruan seperti inilah yang banyak dijumpai di beberapa toko salah satunya di toko pasar Jalan Raya Ciawi. Meski banyak orang mengetahui bahwa hukum jual beli barang tiruan dilarang secara hukum Islam dan melanggar Undang-undang No.28 tahun 2014 tentang Hak Cipta yang berbunyi :

Hak cipta adalah hak eksklusif bagi Pencipta atau penerima hak untuk mengumumkan atau memperbanyak Ciptaannya atau memberikan izin untuk itu

\footnotetext{
${ }^{3}$ Departemen Agama Republik Indonesia, 2007, hlm. 451
} 
Jual Beli Produk Imitasi Fashion Perspektif Undang-Undang Hak Cipta Nomor 28 Tahun 2014 Dan Hukum Islam

dengan tidak mengurangi pembatasan-pembatasan menurut peraturan perundang-undangan yang berlaku. ${ }^{4}$ Sudah jelas ini melanggar Hak Cipta dan dilarang oleh hukum syara'. Apabila ditinjau dari Hukum Islam bahwa faktor ekonomi dan adat kebiasaan yang cenderung lebih memilih kuantitas daripada kwalitas. Penelitian ini akan mencoba meneliti secara lebih mendalam pada praktik jual beli barang imitasi yang berupa tas, sepatu, pakaian, dan lain sebagainya yang mencakup faktor-faktor yang mengakibatkan para penjual dan pembeli barang imitasi dalam melakukan transaksi serta mendepenelitiankan sistem pendistribusian barang imitasi sampai ke tangan konsumen, khususnya yang terdapat di toko pasar Jalan Raya Ciawi.

Sebagai negara yang produktif dalam bidang karya cipta seni dan budaya, tentunya negara wajib melindungi warga negaranya dari permasalahan besar perkembangan hak cipta yaitu pembajakan. Pembajakan menjadi penyakit kronis bagi masyarakat Indonesia saat ini bahkan sebagian masyarakat Indonesia merasa nyaman bergelut dalam dunia pembajakan, baik sebagai pembajak maupun sebagai pembeli produk bajakan. Meningkatnya angka pengangguran setelah krisis ekonomi dan lemahnya penegakan hukum telah membuat industri pembajakan tumbuh dengan pesat dan menciptakan banyak lapangan kerja, baik sebagai pembuat, penyalur, maupun pengecer.

Pelanggaran hak cipta berupa pembajakan dapat diakatakan sebagai tindakan pencurian artinya harta berupa hak cipta tersebut yang dimiliki oleh seseorang telah di ambil atau dicuri oleh orang lain. Dalam hukum Islam telah dijelaskan mengenai hukum mencuri harta milik sesorang yang bukan haknya. Quraish Shihab dalam Tafsir Al-Mishbah menjelaskan arti mencuri yaitu mengambil secara sembunyi sembunyi barang berharga milik orang lain yang disimpan oleh pemiliknya pada tempat yang wajar, dan si pencuri tidak diizinkan untuk memasuki tempat itu. ${ }^{5}$

Pengaturan hak cipta dalam hukum Islam yang berkembang di Indonesia sebenarnya sudah diatur dalam fatwa Majelis Ulama Indonesia (MUI) Nomor 1 Tahun 2003 Tentang Hak Cipta. Dalam fatwa tersebut MUI memandang perlu adanya aturan ataupun ketetapan para ahli hukum Islam (Ulama) tentang status hukum Islam mengenai pembajakan hak cipta untuk menjadi pedoman bagi umat Islam dan pihak-pihak yang memerlukannya. Namun dalam isi fatwa tersebut terdapat ketidakjelasan mengenai sebab atau pertimbangan ilmiahnya dikarenakan fatwa tersebut hanya berdasar dari satu persepsi saja yaitu dari sisi hukum Islam dan tidak disinggung dari sisi yuridis sesuai aturan hukum yang

\footnotetext{
${ }^{4}$ Pasal 1 angka 1 Undang-Undang No.28 tahun 2014 tentang Hak Cipta

${ }^{5}$ M. Quraish Shihab, Tafsir Al-Mishbah: Pesan, Kesandan Keserasian Al-Qur'an (Tangerang : Lentera Hati, 2008), hlm. 93
} 
Jual Beli Produk Imitasi Fashion Perspektif Undang-Undang Hak Cipta Nomor 28 Tahun 2014 Dan Hukum Islam

digunakan di Indonesia. Berangkat dari latar belakang di atas, penyusun tertarik untuk mengkaji lebih mendalam tentang jual beli barang $\mathrm{KW} /$ Imitasi dari sudut pandang Hukum Islam.

\section{METODOLOGI PENELITIAN}

Jenis penelitian yang digunakan adalah penelitian lapangan (field research) yaitu, kegiatan penelitian yang dilakukan secara rinci suatu subjek tunggal, satu kumpulan dokumen, atau suatu kejadian tertentu. Penelitian ini dengan pendekatan kualitatif, yaitu menekankan analisis proses berpikir secara induktif yang berkaitan dengan dinamika hubungan antar fenomena yang diamati dan menggunakan logika ilmiah yang diperoleh penulis berdasarkan data dari lapangan. Penelitian ini dilaksanakan di toko pasar Jalan Raya Ciawi.

Sampel

Konsep sampel dalam penelitian ini adalah bagian kecil dari anggota populasi yang diambil menurut prosedur tertentu sehingga dapat mewakili populasinya secara representatif. Jenis sampel yang digunakan peneliti yaitu purposife sampling, dalam teknik ini peneliti mengambil sampel berdasarkan kepada ciri-ciri yang dimiliki oleh subjek yang dipilih karena ciri-ciri tersebut sesuai dengan tujuan penelitian yang akan dilakukan. Dalam penelitian ini mengambil sampel dari konsumen yang mengalami permasalahan produk gandaan/barang KW jenis fashion.

Sumber Data

Menurut sumbernya, data penelitian digolongkan sebagai data primer dan data sekunder.

Data Primer

Data primer adalah data yang berasal dari sumber asli atau sumber pertama yang secara umum kita sebut sebagai narasumber. Data primer ini penulis dapatkan melalui wawancara langsung dengan karyawan, pembeli (konsumen) dan pihak manajemen/pengelola toko di pasar tersebut.

Data Sekunder

Data sekunder adalah data yang sudah di proses oleh pihak tertentu sehingga data tersebut sudah tersedia saat kita memerlukan. Dalam penelitian ini yang menjadi data sekunder adalah dokumen-dokumen, buku-buku dan data-data lain yang berkaitan dengan judul penelitian.

Metode Pengumpulan Data

Metode pengumpulan data yang digunakan dalam penelitian ini adalah : Wawancara

Wawancara atau yang sering disebut interview adalah percakapan dengan maksud tertentu. percakapan itu dilakukan oleh dua pihak, yaitu pewawancara (interviewer) yang mengajukan pertanyaan dan terwawancara (interview) yang memberikan jawaban atas pertanyaan itu. Dalam hal ini penulis melakukan 
Jual Beli Produk Imitasi Fashion Perspektif Undang-Undang Hak Cipta Nomor 28 Tahun 2014 Dan Hukum Islam

wawancara yang bersifat struktural. Yaitu, sebelumnya penulis telah menyiapkan daftar pertanyaan spesifik yang berkaitan dengan permasalahn yang akan dibahas sehingga terfokus pada pokok permasalahan. Dalam teknik wawancara ini penulis melakukan wawancara dengan penjual (karyawan) dan produsen yang menghasilkan barang tersebut.

Dokumentasi

Metode dokumentasi ini sumber datanya berupa dokumen- dokumen yang tersedia dan berkaitan dengan objek penelitian. Seperti gambaran tentang letak geografis pasar Ciawi, arsip-arsip dan data-data yang mendukung dalam penelitian ini.

\section{Analisis Data}

Analisis data adalah proses mencari dan menyusun secara sistematis data yang diperoleh dari hasil interview, catatan lapangan, observasi, dokumentasi dengan cara mengorganisasikan data ke dalam kategori, menjabarkan dan membuat kesimpulan yang dapat dipahami oleh diri sendiri maupun orang lain. Setelah data terkumpul, kemudian data diolah dan dianalisis dengan menggunakan metode deskriptif yaitu metode analisis yang menekankan pada pemberian sebuah gambaran baru terhadap data yang telah terkumpul.

\section{PEMBAHASAN HASIL PENELITIAN}

\section{Gambaran Umum Lokasi Penelitian}

Pasar adalah adanya penjual dan pembeli saling bertemu, salah satu dari berbagai sistem, institusi, prosedur, hubungan sosial dan infrastruktur dimana usaha menjual barang, jasa, dan tenaga kerja untuk orang-orang dengan imbalan uang. Barang dan jasa yang dijual menggunakan alat pembayaran yang sah seperti uang fiat. Kegiatan ini merupakan bagian dari perekonomian. Ini adalah pengaturan yang memungkinkan pembeli dan penjual untuk item pertukaran. Persaingan sangat penting dalam pasar, dan memisahkan pasar dari perdagangan. Dua orang mungkin melakukan perdagangan, tetapi dibutuhkan setidaknya tiga orang untuk memiliki pasar, sehingga ada persaingan pada setidaknya satu dari dua belah pihak. Pasar bervariasi dalam ukuran, jangkauan, skala geografis, lokasi jenis dan berbagai komunitas manusia, serta jenis barang dan jasa yang diperdagangkan.

Beberapa contoh termasuk pasar petani lokal yang diadakan di alun-alun kota atau tempat parkir, pusat perbelanjaan dan pusat perbelanjaan, mata uang internasional dan pasar komoditas, hukum menciptakan pasar seperti untuk izin polusi, dan pasar ilegal seperti pasar untuk obat-obatan terlarang. ${ }^{6}$ Pasar dibagi 2:

\footnotetext{
${ }^{6}$ https://id.wikipedia.org/wiki/Pasar, Pukul : 09.42
} 
Jual Beli Produk Imitasi Fashion Perspektif Undang-Undang Hak Cipta Nomor 28 Tahun 2014 Dan Hukum Islam

\section{a. Pasar Tradisional}

Pasar tradisional merupakan tempat bertemunya penjual dan pembeli serta ditandai dengan adanya transaksi penjual pembeli secara langsung dan biasanya ada proses tawar-menawar, bangunan biasanya terdiri dari kios-kios atau gerai, los dan dasaran terbuka yang dibuka oleh penjual maupun suatu pengelola pasar. Kebanyakan menjual kebutuhan sehari-hari seperti bahan-bahan makanan berupa ikan, buah, sayur-sayuran, telur, daging, kain, pakaian barang elektronik, jasa dan lain-lain. Selain itu, ada pula yang menjual kue-kue dan barang-barang lainnya. Pasar seperti ini masih banyak ditemukan di Indonesia, dan umumnya terletak dekat kawasan perumahan agar memudahkan pembeli untuk mencapai pasar. Beberapa pasar tradisional yang "legendaris" antara lain adalah pasar Beringharjo di Yogyakarta, pasar Klewer di Solo, pasar Johar di Semarang. Pasar tradisional di seluruh Indonesia terus mencoba bertahan menghadapi serangan dari pasar modern.

\section{b. Pasar modern}

Pasar modern tidak banyak berbeda dari pasar tradisional, namun pasar jenis ini penjual dan pembeli tidak bertransakasi secara langsung melainkan pembeli melihat label harga yang tercantum dalam barang (barcode), berada dalam bangunan dan pelayanannya dilakukan secara mandiri (swalayan) atau dilayani oleh pramuniaga. Barang-barang yang dijual, selain bahan makanan makanan seperti; buah, sayuran, daging; sebagian besar barang lainnya yang dijual adalah barang yang dapat bertahan lama. Contoh dari pasar modern adalah hypermart, pasar swalayan (supermarket), dan minimarket.

\section{Sejarah Pasar Ciawi}

Pasar Tradisional Ciawi ini menjadi pusat bisnis di kabupaten Ciawi. karena hampir semua pedagang ada di sini mulai dari Toko emas, kelontong, kosmetik dan lain-lain. Baik pedagang partai besar sampai pedagang kaki lima, lokasi pasar ada di Jalan Pelita jaya Ciawi Tasikmalaya. Kalo dari arah Bandung belok kiri arah ke alun-alun Ciawi tepat depan pom bensin sebelah kanan. Kalo dari arah Rajapolah belok kanan di daerah Panyusuhan. Tepat di depan pasar ada terminal tempat angkutan umum jurusan Ciawi-Tasik, Limbangan. Jalur ini adalah jalur bis luar kota maupun dalam kota pasti lewati terminal Ciawi in, suasana pasar masih ramai karena biasanya pedagang berdatangan dari jam 3 pagi sampai jam 3 sore.

Pasar Ciawi terletak di kota Tasikmalaya, Pasar tradisional yang terpencil dan sangat strategis ini banyak dikunjungi warga untuk berbelanja atau interaksi dimana penjual dan pembeli bertemu di pasar Ciawi ini. Pasar ini berdiri pada tahun 1992 yang diberi nama UPTD akan tetapi pada tahun 2016 pasar ini diganti nama jadi UPT pasar Jalan Raya Ciawi. Sebelum tahun 1992 tempat yang 
Jual Beli Produk Imitasi Fashion Perspektif Undang-Undang Hak Cipta Nomor 28 Tahun 2014 Dan Hukum Islam

sebelumnya dijadikan UPT ini yaitu terminal bus/angkutan. Banyak macam yang diperjual belikan di pasar ini untuk kebutuhan sehari-hari contohnya seperti makanan sayuran dan pakaian.

\section{Lokasi dan batas-batas pasar}

Lokasi ini dibagi 2 : Lokasi Pasar dan Lokasi Terminal. Yang dimana lokasi terminal jumlah luas keseluruhannya mencapai $2.410 \mathrm{~m} 2$ dan luas pasar keseluruhannya mencapai 10.055 m2. Lokasi Pasar terdapat 4 blok : blok A, blok $B$, blok $C$, dan Blok $D$ yang masing- masing mempunyai kelas dan ukuran luas kios.

Blok A : Kelas I $3 \times 5$ Jumlah 68 kios $=1.020 \mathrm{~m} 2$

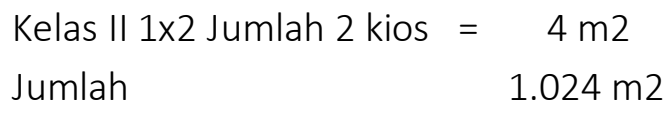

Blok B : Kelas I 3x3 Jumlah 4 kios $=36 \mathrm{~m} 2$

Kelas II 2,5x3 Jumlah 148 kios $\quad=1.110 \mathrm{~m} 2$

Jumlah

$1.146 \mathrm{~m} 2$

Blok C: Kelas I $3 \times 3$ Jumlah 8 kios $=72 \mathrm{~m} 2$

$2,5 \times 2,5$ Jumlah 4 kios $\quad=25 \mathrm{~m} 2$

$2 \times 2,5$ Jumlah 13 kios $\quad=65 \mathrm{~m} 2$

Kelas II 2,5x3 Jumlah 120 kios $\quad=900 \mathrm{~m} 2$

$2 \times 2,5$ Jumlah 13 kios $\quad=65 \mathrm{~m} 2$

Jumlah $1.127 \mathrm{~m} 2$

Blok D : Kelas I $3 \times 3$ Jumlah 4 kios $=36 \mathrm{~m} 2$

Kelas II 2,5x3 Jumlah 148 kios $\quad=1.110 \mathrm{~m} 2$

Jumlah $1.146 \mathrm{~m} 2$

Total luas kios $4.443 \mathrm{~m} 2$,Gang 1.858 m2, Rabat 556 m2, Jalan Lingkungan 3.150 m2, Kantor UPTD Pasar Ciawi 48 m2.

\section{Struktur organisasi}

Dibentuknya struktur organisasi di pasar Ciawi adalah untuk memberi batas kewenangan terhadap setiap bagian atau setiap unit kerja yang ada, sehingga mereka dapat mempertanggung jawabkan apa yang dikerjakannya. Lebih jelasnya dibawah ini dapat dilihat uraian tugas Di UPT Pasar Ciawi. ${ }^{7}$

a. Ketua adalah seorang yang mengepalai pasar yang berkedudukan

sebagai unsur pelaksana di bidang pasar yang mempunyai tanggung jawab dan tugas sebagai berikut:

? Melaksanakan segala usaha dan kegiatan pengaturan pemungutan, pengumpulan dan pemasukan pendapatan daerah di bidang pengelolaan pasar berdasarkan kebijaksanaan yang ditetapkan oleh kepala daerah dan perundangundangan yang

berlaku.

\footnotetext{
${ }^{7}$ Dokumentasi Profil UPT Pasar Ciawi 2 Agustus 2018
} 
Jual Beli Produk Imitasi Fashion Perspektif Undang-Undang Hak Cipta Nomor 28 Tahun 2014 Dan Hukum Islam

? Mengkoordinasikan seluruh usaha dibidang pengelolaan pasar dalam berdasarkan ketentuan-ketentuan baik yang telah digariskan oleh pemerintah daerah maupun instansi yang tinggi.

[? Mengikuti perkembangan keadaan secara terus-menerus dan memperhatikan akibat atau pengaruh-pengaruh dari keadaan itu terhadap pelaksanaan tugas pokok.

? Mengumpulkan, mengelompokkan dan mengolah data dan bahan bahan mengenai atau yang berhubungan dengan pelaksanan tugas pokok.

? Membuat rancangan dan program yang diperlukan bagi penyelenggaraan tugas pokok.

[? Melaksanakan tugas-tugas lain dengan tugas dan fungsi sebagai ketua.

b. Bidang Keuangan mempunyai tugas dan tanggung jawab sebagai berikut:

? Merumuskan dan mengkoordinasikan pembinaan bidang keuangan

? Menyiapkan laporan keuangan

? Merencanakan program kerja pengelolaan biaya operasional rumah tangga

? Melaporkan laporan keuangan secara lisan maupun tertulis kepada atasan.c. Bidang Restribusi mempunyai tugas dan tanggung jawab sebagai berikut:

? Merumuskan dan melaksanakan pengelolaan dan pembinaan kekaryawanan, tata usaha, umum, rumah tangga dan perlengkapan serta kearsipan.

? Merumuskan dan melaksanakan kegiatan dokumentasi serta pengolahan data dan informasi yang berhubungan dengan bidang kekaryawanan di pasar.

? Merumuskan dan melaksanakan pengembangan pasar dibidang restribusi pengelolaan pasar khusunya yang menyangkut teknis administrasi.

d. Bidang Kebersihan dan Ketertiban, mempunyai rincian tugas sebagai berikut:

? Mengkoordinasikan, membina dan merumuskan penyusunan ketertiban dan kebersihan serta penyusunan rencana kerja tahunan.

? Mengkoordinasikan, membina dan merumuskan pengaturan serta penyelesaian masalah ketertiban dan kebersihan.

? Mengkoordinasikan, membina dan merumuskan di bidang ketertiban, keamanan, dan kebersihan pasar.

Secara struktural organisasi UPT pasar Ciawi adalah sebagai berikut:

\section{Struktur UPT Pasar Ciawi}

Kapala UPT :Halen Wahyudi, SE Kasubag Kepegawaian :Enang

Sutisna

Bendahara :Iwan 
Jual Beli Produk Imitasi Fashion Perspektif Undang-Undang Hak Cipta Nomor 28 Tahun 2014 Dan Hukum Islam

Petugas Harian:Ipan, Ari, Gugun

Petugas Langganan :Jenar Rusdiana

Kepegawaian :Wawan

Petugas Keamanan :A.Suharto, Engkus Hermawan, Epin, Nono, Hafidz, Zenal

Petugas Kebersihan :Imang, Enjah, Agus, Didi, lip, Nana, ling

\section{Aktivitas perdagangan UPT Pasar Ciawi}

Pada dasarnya masyarakat pedagang pasar Ciawi merupakan masyarakat yang ramah. Bahasa yang digunakan oleh pedagang pasar bahasa yang ramah, maka dari itu banyak pembeli yang minat untuk berbelanja disana. Jenis usaha yang dilakukan para pedagang di Pasar Ciawi bermacam-macam, sesuai dengan minat pedagang dan yang paling penting adalah sesuai dengan modal yang dimilikinya. Pedagang yang memiliki modal besar bisa leluasa mengontrak kios atau los yang telah disediakan. Namun tidak sedikit pedagang yang menggunakan lahan kaki lima untuk melakukan perdagangan karena keterbatasan modalnya. Kebanyakan pedagang yang menggunakan lahan kaki lima adalah para pedagang kecil yang menjual makanan berupa sayuran, tahu, tempe, kue, bumbu masakan dan ada juga yang menjual pakaian obralan dan aksesoris. ${ }^{8}$

\section{Praktik Jual Beli Produk Imitasi jenis Fashion di Toko Pasar Jalan Raya Ciawi}

\section{Penjual}

Pasar Ciawi sangat bermanfaat untuk memenuhi kebutuhan masyarakat di sekitarnya maupun daerah lain selain Ciawi, yang dikarenakan pasar ini letaknya sangat strategis. Untuk memenuhi kebutuhan masyarakat tersebut yang sangat beragam, maka setiap pedagang harus dapat memenuhi setiap permintaan pembeli termasuk permintaan dari segi produk imitasi. Untuk itu barang yang dijual tidak hanya sejenis melainkan bermacam-macam. Dalam melatar belakangi keberhasilan Rasulullah SAW dalam berdagang atau berbisnis salah satunya adalah beliau menerapkan prinsip-prinsip dagang yakni jujur dan tabligh. Karena sikap jujur dan tabligh ini sangat penting bagi pembisnis, karena sikap ini berkaitan dengan bagaimana seorang pembisnis bisa meyakinkan calon pembeli dengan kemampuan komunikasi yang dimilikinya sehingga pembeli tertarik untuk membeli produk tersebut. Begitu juga dengan pedagang yang ada dipasar Ciawi pada sebagiannya ada yang memberikan informasi kepada konsumennya dan ada juga yang sama sekali tidak memberitahukan bahwa produk yang dijual tersebut barang tiruan dan bukan barang asli dengan alasan bahwa terlalu repot dan lama untuk menjelaskan kepada konsumen. ${ }^{9}$

\footnotetext{
8 Jenar rusdiana, (Sie.Restribusi Langgana UPT Pasar Ciawi), Wawancara, Ciawi, 2 Agustus 2018.

${ }^{9}$ Alpa, (Penjual produk imitasi), Wawancara, Ciawi, 2 Agustus 2018
} 
Jual Beli Produk Imitasi Fashion Perspektif Undang-Undang Hak Cipta Nomor 28 Tahun 2014 Dan Hukum Islam

Umumnya produk imitasi atau KW alias KWalitas tiruan kwalitas nomer 2, 3, dan seterusnya adalah bukan asli/original, untuk masyarakat dengan ekonomi bawah atau pas-pasan serupa tapi tak sama. Terjadinya produk KW itu umumnya karena memang produk asli kurang terjangkau untuk masyarakat luas sedangkan animo begitu tinggi. Tetapi, terkadang jikalau "terlalu" banyak dibuat produk KW maka KWalitas asli atau sesungguhnya dari produk bukan tiruan itu seolah menjadi "kabur".

Sebab dalam sebuah perbincangan, penulis menemukan sebuah pendapat baru bahwa tidak semua barang imitasi kwalitasnya rendah, pada kenyataannya banyak barang imitasi sudah mulai menyamai kwalitas dari barang yang diimitasinya. Bahkan ada beberapa penjual produk imitasi yang berani menyatakan bahwa produk yang ditawarkannya tidak kalah dengan produk aslinya.

Dilihat dari kwalitas barang imitasi tersebut maka penjual tidak dapat menetapkan harga sesuai dengan barang asli, dikarenakan barang imitasi tersebut hanya barang tiruan yang harga dari agen lebih murah dibandingkan barang asli, sehingga penjual tidak dapat menetapkan sepihak saja dengan menjual barang tersebut dengan harga yang mahal. Hal ini disebabkan karena pada beberapa pedagang terdapat sebuah kesepakatan harga yang harus dipatuhi oleh semua pedagang produk yang sejenis. Harga yang bervariasi memang sangat mungkin namun, pada kenyataannya di beberapa lokasi terdapat keseragaman harga yang tidak dapat dihindari untuk mencegah persaingan yang tidak sehat antar pedagang. ${ }^{10}$

Produk imitasi jenis fashion yang beredar di Toko pasar Jalan Raya Ciawi Tasikmalaya berjumlah sangat banyak dan beragam. Dalam penelitian ini yang menjadi sorotan penulis adalah produk jenis fashion yang diproduksi oleh industri yang relatif kecil meniru dengan sempurna atau meniru bagian tertentu dari sebuah produk yang sudah ada sebelumnya. Atau dengan kata lain penulis akan menyebutnya sebagai produk fashion imitasi untuk memudahkan responden mengerti akan objek penelitian yang diteliti, maka penulis memberikan contoh objek penelitian adalah produk fashion yang sering dikonsumsi oleh responden seperti tas, sepatu, topi, jam tangan, jacket dan produk-produk fashion lainnya yang meniru produk sejenis yang pernah ada atau sedang dipasarkan. Kesemuanya penulis kategorikan menjadi satu kategori yaitu produk imitasi jenis fashion, sehingga dalam penyebutan selanjutnya produk-produk tersebut disebut sebagai produk imitasi jenis fashion. Pasar Ciawi sangat bermanfaat untuk memenuhi kebutuhan masyarakat di sekitarnya, bahkan sudah banyak diantara masyarakatnya yang sudah lama mencari nafkah dengan cara berjualan produk imitasi disana.

${ }^{10}$ Yani, (Penjual produk imitasi), Wawancara, Ciawi ,2 Agustus 2018 
Jual Beli Produk Imitasi Fashion Perspektif Undang-Undang Hak Cipta Nomor 28 Tahun 2014 Dan Hukum Islam

Setiap kegiatan manusia, tentu ada yang melatar belakangi untuk melakukan halhal tersebut, begitu juga yang terjadi pada para penjual produk imitasi. Faktorfaktor atau alasan yang mendorong para pedagang berjualan produk imitasi adalah karena lebih menguntungkan, minat masyarakat yang besar terhadap produk imitasi, menambah penghasilan, dan karena faktor adat kebiasaan masyarakat/ikut-ikutan.

\section{Pembeli}

Aneka barang dari mulai sepatu branded hingga jacket kickers banyak terjual di beberapa toko di pasar Ciawi. Tapi jangan berharap barang barang yang dijual murah itu asli. Karena segala barang-barang branded ternyata semuanya imitasi, dijual pun dengan harga miring. Pada dasarnya tidak semua pembeli atau konsumen mengetahui produk-produk atau barang-barang dibelinya merupakan barang imitasi. Dan dengan kesempatan inilah digunakan oleh penjual untuk melabui pembeli dengan cara membohongi pembeli bahwa barang yang dijualnya memiliki kwalitas barang yang sama dengan yang aslinya. Seperti halnya yang dialami oleh Fery, ia mengatakan: ketika ia berbelanja di pasar Ciawi tepatnya disalah satu kios yang menjual barang imitasi, yang ingin dibeli oleh Fery adalah sepatu, maka segeralah pedagang ini mengambilkan sepatu yang bermerek itu untuk ditunjukkan ke Fery, dan pedagang mengatakan bahwa "barang tersebut memiliki kwalitas barang yang sama dengan yang dijual di toko- toko lain yang dijual "mahal" dengan perkataan tersebut Fery pun tertarik. Namun kenyataannnya kwalitas barang yang dijualnya jauh dibawah sepatu merek yang asli dengan demikian Fery merasa tertipu. ${ }^{11}$

Tanggapan pembeli alasan memilih produk imitasi jenis fashion mengatakan dilatar belakangi karena harga yang terjangkau, karena kwalitas barang dan karena kebutuhan. Pasar Ciawi ini merupakan pasar yang menjual produk imitasi terbanyak di daerahnya. Banyak orang yang telah mengetahui pasar ini sehingga pasar ini ramai dikunjungi oleh pembeli. Masyarakat tahu keberadaan produk imitasi ini kebanyakan dari mulut kemulut. Akan tetapi tidak semua pembeli disini mengetahui tempat-tempat yang menjual barang imitasi dikarena kan banyak pembeli yang datang pada dasarnya tidak berasal dari Ciawi atau berasal dari daerah-daerah lainnya. Selain itu, warga disekitar banyak merupakan warga pendatang yang bekerja di sana karena Ciawi merupakan daerah yang strategis.

Setiap pembeli adalah raja, dan pembeli pasti tidak ingin dirugikan karena mereka harus mengeluarkan biaya untuk memperoleh suatu barang yang dinginkannya dengan cara dibeli. Untuk itu sering sekali pembeli komplain terhadap barang yang telah dibelinya dan adakalanya penjual tidak peduli

${ }^{11}$ Fery, (Pembeli produk imitasi), Wawancara, Ciawi , 2 Agustus 2018 
Jual Beli Produk Imitasi Fashion Perspektif Undang-Undang Hak Cipta Nomor 28 Tahun 2014 Dan Hukum Islam

terhadap komplain para pembeli, dengan alasan barang yang telah dibeli tidak dapat dikembalikan.

\section{Jual Beli Produk Imitasi ditinjau dari Undang-Undang Nomor 28 Tahun 2014} Tentang Hak Cipta

Di dalam Undang-Undang hak cipta sendiri nyatanya banyak sekali pasalpasal yang terkesan multitafsir sehingga tidak mengandung kepastian hukum. Di dalam Undang-Undang hak cipta 2002, tidak tergambar secara jelas adanya perlindungan hak ekonomi dan hak moral bagi para pencipta dan pemegang hak terkait. Selain itu juga terdapat adanya hal-hal dan penemuan baru di dalam masyarakat yang perlu untuk dimasukkan ke dalam materi penggantian Undang-Undang hak cipta, dalm Undang-Undang hak cipta terdapat materi baru bagi pencipta dan p3m3gang hak terkait, misalnya mengenai penggunaan hak cipta dan hak terkait dalam sarana multimedia untuk merespon perkembangan teknologi informasi dan komunikasi, masalah pembajakan, materi delik aduan, dan sebagainya.

Terkait dengan hal tersebut maka DPR RI bersama-sama dengan Pemerintah melakukan adanya pembaharuan hukum melalui penggantian Undang-Undang hak cipta. Hal ini dilakukan dengan tujuan untuk menciptakan adanya jaminan perlindungan dan kepastian hukum agar lebih memperhatikan kepentingan para pencipta dan pemegang hak terkait. Keharusan perlindungan terhadap HAKI khususya hak cipta yang terdapat pada Undang-Undang Nomor 28 Tahun 2014 Tentang hak cipta, hal ini sesuai dengan dasar kemaslahatan pemilik ide dan kreasi, sebab tanpa perlindungan yang jelas, semua orang bebas untuk mengklaim bahwa ide dan kreasi tersebut adalah miliknya sekalipun hanya menjiplak. Orisinalitas ide, pemikiran dan kreasi menjadi simpang siur tanpa aturan yang jelas. Ini diperkuat lagi dengan maraknya pembajakan intectual property (karya ilmiah, karya seni, karya satra, dan lain-lain).

Jika dicermati sebenarnya Indonesia telah lama mempunyai undangundang yang mengatur mengenai hak cipta, terakhir adalah Undang-Undang hak cipta 2002 tentang hak cipta. Akan tetapi karena perkembangan jaman dan keadaan yang begitu cepat, khususnya di bidang teknologi informasi dan komunikasi serta perubahan lingkungan yang strategis, baik lokal maupun internasional, maka penggantian terhadap Undnag-Undang hak cipta 2002 jelas menjadi sebuah kebutuhan bagi masyarakat. Hal ini di dukung dengan maraknya fenomena empiris tentang pembajakan, pemalsuan dan pelanggaran terhadap karya-karya hak cipta, yang secara tidak langsung dapat menimbulkan ketidakpastian jaminan hukum.

Selain itu juga dalam prakteknya, hak-hak pencipta belum sepenuhnya dijamin di dalam Undang-Undang hak cipta. Maksudnya di dalam Undang-Undang 
Jual Beli Produk Imitasi Fashion Perspektif Undang-Undang Hak Cipta Nomor 28 Tahun 2014 Dan Hukum Islam

hak cipta 2002, hak-hak pencipta dirumuskan secara global yakni hak untuk mengumumkan dan memperbanyak sehingga hak-hak pencipta yang lainnya tidak secara eksplisit dinyatakan dalam rumusan Pasal 2 ayat (1). Hal ini tentu saja sangat berpengaruh terhadap pencipta dalam mengekspolitasi hak ekonomi yang dimilikinya karena menjadi kurang terlindungi dan tidak memiliki dasar hukum yang kuat. Kemudian berdasarkan praktik di masyarakat, pemberlakuan delik biasa atas tindak pidana di bidang hak cipta ternyata dirasakan kurang tepat untuk diberlakukan. Hal ini dikarenakan hak cipta merupakan hak keperdataan yang bersifat eksklusif, sehingga idealnya pelanggaran atas hak cipta adalah delik aduan karena yang paling mengetahui adanya pemalsuan atas suatu ciptaan adalah pencipta itu sendiri. Hal ini kemudian diperjelas dengan adanya hal beban pembuktian, di mana penyidik dirasakan akan menjadi kesulitan untuk membuktikan adanya tindak pidana di bidang hak cipta tanpa adanya laporan dari pemegang hak. Memang tidak dipungkiri bahwa meskipun Undnag-Undnag hak cipta

2002 telah mengatur mengenai perlindungan hak cipta berikut tahap-tahap mekanisme pendaftaran akan tetapi nyatanya masih terdapat banyak hambatan atau kendala di lapangan. Hal ini dikarenakan pengaturan di dalam UndangUndang hak cipta 2002 sudah dianggap tidak sesuai dengan kondisi kekinian yang ada di Indonesia, sehingga materi-materi yang tercakup di dalam undangundang tersebut harus diubah secara menyeluruh bukan hanya diubah secara sebagian.

\section{Jual Beli Produk Imitasi ditinjau dari Hukum Islam}

Pembajakan hak cipta yang di dalam undang-undang hak cipta masuk dalam ranah pidana. Sama halnya dengan pembajakan hak cipta dalam hukum Islam. Dalam hukum Islam hukum pidana disebut dengan jinayat. Secara terminologi istilah jinayat menurut pendapat para ahli fiqih adalah perbuatan yang dilarang oleh syara' baik mengenai jiwa, harta atau lainnya. Analogi yang paling rasional terhadap pelanggaran hak cipta terutama mengenai pembajakan dalam konteks Islam adalah dengan tindak pidana pencurian atau Syaraqah. Unsur dari pencurian yaitu:

a) Pengambilan secara diam-diam ;

b) Barang yang diambil merupakan harta ;

c) Harta tersebut milik orang lain ;

d) Adanya niat melawan hukum ;

Larangan untuk pencurian jelas tercantum dalam Q.S Al-Baqarah ayat 188 yang berarti :

Dan janganlah sebahagian kamu memakan harta sebahagian yang lain di antara kamu dengan jalan yang batil dan (janganlah) kamu membawa(urusan) harta itu kepada hakim, supaya kamu dapat 
Jual Beli Produk Imitasi Fashion Perspektif Undang-Undang Hak Cipta Nomor 28 Tahun 2014 Dan Hukum Islam

memakan sebahagian daripada harta benda orang lain itu dengan (jalan berbuat) dosa, padahal kamu mengetahui

Untuk menentukan status hukum dari pembajakan dengan menyamakan hukum dari pencurian dapat menggunakan metode qiyas. Qiyas adalah mempersamakan hukum suatu perkara yang belum ada ketetapan hukumnya dengan perkara yang sudah ada ketentuan hukumnya. Persamaan ketentuan hukum dimaksud didasari oleh adanya persamaan unsur-unsur kesamaan yang sudah ada ketetapan hukumnya dengan yang belum ada ketetapan hukumnya yang disebut dengan illat. Agar mempermudah dalam penentuannya kita lihat bagan dibawah ini :

\begin{tabular}{l|l}
\multicolumn{1}{l}{ Ashal } & Pencurian Harta \\
\hline Far'un & $\begin{array}{c}\text { Pembajakan Hak Cipta } \\
\text { Haram ( mengacu pada } \\
\text { OS Al-Maidah : 38) }\end{array}$ \\
\hline Illat Hukum & -Hak cipta merupakan dari harta. \\
& -Adanya pembajakan \\
memiliki kesamaan pengertian \\
dengan pencurian karena \\
sama sama mengambil hak \\
orang lain yang bukan \\
merupakan hak nya.
\end{tabular}

Penjelasan :

a) Ashal

Adapun ashal merupakan kasus yang sudah ditetapkan dalam Al- Qur'an atau hadits. Ada beberapa ulama menegaskan mengenai syarat ashal yaitu harus ada dalil/petunjuk didalam Al-Qur'an ataupun hadits serta adanya kesepakatan seluruh ulama tentang adanya sebab / illat yg menjadikan ashal itu sesuai dengan Al-Qur'an dan Hadits. Dalam contoh kasus di atas, jelas bahwa ashal sudah ditentukan dalam Al-Qur"an dalam surat Al-Maidah ayat 38 yang berarti:

Laki-laki yang mencuri dan perempua yang mencuri, potonglah tangan keduannya, sebagai pembalasan apa yang mereka kerjakan dan sebagai siksaan dari Allah. Dan Allah maha perkasa lagi maha bijaksana.

b) Far"un

Ialah Hukum yang belum ada ketetapan hukumnya berdasarkan teks AlQur'an dan hadits yang ingin disamakan hukumnya dengan ashal.Adapun 
Jual Beli Produk Imitasi Fashion Perspektif Undang-Undang Hak Cipta Nomor 28 Tahun 2014 Dan Hukum Islam

menurut ulama far'un harus memiliki kesamaan dengan illat ashal, selain itu harus ada kesamaan mengenai hukumnya.

Dalam contoh kasus di atas, pembajakan belum diatur dan disebutkan teksnya di dalam Al-Qur'an maupun Hadits. Selain itu adanya kesamaan illat ashal merujuk pada definisi dari pembajakan menurut Undang-Undang Nomor 28 Tahun 2014 pasal 1 angka 23 yaitu penggandaan ciptaan dan/atau produk hak terkait secara tidak sah dan pendistribusian barang hasil penggandaan dimaksud secara luas untuk memperoleh keuntungan ekonomi.

c) Hukum Ashal

Hukum syara' yang ditetapkan oleh nash pada ashal dan ingin ditetapkan juga pada far'un. Adapun syarat hukum ashal adalah :

1. Hukum ashal harus merupakan hukum syara'. Hukum syara disini merupakan firman Allah SWT yang mengatur amal perbuatan orang mukalaf, baik berupa perintah, larangam, anjuran. Adapun hukum syara" yang sering digunakan adalah hukum taklifi dimana hukum tersebut merupakan perintah, larangan dan anjuran. Hukum taklifi dibagi menjadi ; wajib (sesuatu yang diharuskan oleh Allah SWT dan Rasul untuk dilaksanakan oleh tiap mukalaf, apabila dilaksanakan mendapat pahala dan bila ditinggalkan mendapat dosa), Mandub (sesuatu perbuatan yang dianjurkan oleh Allah SWT dan rasul,mendapat pahala bila dilakukan dan tidak dicela bila tidak dilakukan), Haram ( sesuatu yang tidak boleh dilakukan dan harus dijauhi), Makruh (sesuatu yang ditinggalkan mendapat pujian dan apabila dilakukan tidak mendapat celaan), Mubah ( sesuatu yang dilakukan atau tidak dilakukan tidak mendapatkan konsekuensi apapun).

2. Hukum ashal harus berdasarkan Al-Qur'an atau Hadits, tidak boleh berasal dari ra'yu. Berdasarkan contoh kasus di atas, jelas bahwa hukum ashal yang digunakan adalah haram sebagaimana dalam Al-

Qur'an surat Al-Maidah ayat 38 yang berarti :

Laki-laki yang mencuri dan perempuan yang mencuri, potonglah tangan keduannya, sebagai pembalasan apa yang mereka kerjakan dan sebagai siksaan dari Allah. Dan Allah maha perkasa lagi maha bijaksana.

d) Illat Hukum

Sifat yang menjadi dasar penetapan hukum pada ashal dan oleh karena sifat tersebut terdapat pada far'un, maka far'un disamakan hukumnya dengan ashal.Adapun syarat illat adalah mengandung hikmah yang mendorong pelaksanaan suatu hukum, harus bisa dicapai oleh akal manusia, harus dapat diamati oleh manusia, dapat dirasakan oleh semua orang. Dalam contoh kasus di atas illat hukum dari pembajakan adalah :

1) Adapun hak cipta disini sudah disepakati jika hak cipta dimasukkan menjadi bagan dari harta mengacu pada Pasal 16 ayat (1) yaitu Hak Cipta merupakan benda bergerak tidak berwujud. 
Jual Beli Produk Imitasi Fashion Perspektif Undang-Undang Hak Cipta Nomor 28 Tahun 2014 Dan Hukum Islam

2) Definisi dari pembajakan menurut Undang-Undang Nomor 28 Tahun 2014 pasal 1 angka 23 yaitu penggandaan ciptaan dan/atau produk hak terkait secara tidak sah dan pendistribusian barang hasil penggandaan dimaksud secara luas untuk memperoleh keuntungan ekonomi memiliki persamaan dengan pencurian.

3) Hak cipta yang dibajak oleh pembajak merupakan harta berdasarkan pasal 16 Undang-Undang Hak Cipta yang dilindungi oleh undang- undang hal ini selaras dengan objek pencurian yang berupa harta yang berada dalam kepemilikan seseorang.

4) Adapun unsur pencurian yaitu barang yang diambil oleh pencuri diambil secara diam diam dan memang disiman di di tempatnya. Hal tersebut sama dengan pembajakan dimana ciptaan yang dibajak diambil secara tidak sah dan memang hak cipta tersebut sudah dilindung undang-undang.

Mengenai bentuk dari pembajakan dalam pandangan Islam tidaklah diatur dalam teks Al-Qur'an nya dikarenakan pembajakan pun tidak diatur apalagi mengenai bentuk bentuk pembajakanya. Namun apabila dikaji berdasarkan hasil Qiyas di atas maka segala apapun bentuk dari pembajakan merupakan haram dan harus dijauhi. Dengan beberapa penjelasan di atas maka segala apapun bentuk pembajakan baik cara atau metode maupun objek atau sasaran yang mengarah pada pembajakan hak cipta hukumnya adalah haram.

\section{SIMPULAN}

Penelitian ini mengaji hukum yang dipandang dari dua perspektif yang berbeda yaitu berdasarkan hukum Undang-Undang Hak Cipta dan hukum Islam, isu hukum tersebut harus dikupas secara komprehensif berdasarkan masingmasing perpektif. Dalam hukum nasional, hak cipta secara tegas diatur dalam Undang-Undang Nomor 28 Tahun 2014 Tentang hak cipta dan tindakan pidana pencurian atas hasil pemikiran manusia yang tercantum pada pasal 114,Pasal 113 Undang-Undang hak cipta.

Sedangkan dalam hukum Islam, pengaturan hak cipta secara eksplisit tidak diatur dalam sumber hukum utama hukum Islam yaitu Al- Qur"an dan Hadits, namun konsep dasar mengenai hak cipta akan di analogikan oleh penulis dengan konsep kepemilikan harta dalam pandangan fiqih Islam. Alasan penggunaan dasar tersebut karena hak cipta berdasarkan pasal 16 ayat (1) Undang-Undang No 28 Tahun 2014 Tentang Hak Cipta menyebutkan jika hak cipta merupakan benda bergerak yang tidak berwujud. Oleh karena itu, dalam pandangan Islam setiap benda yang dimiliki seseorang yang merupakan hak atas kepemilikannya maka disebut dengan harta. Analogi yang paling rasional terhadap pelanggaran hak cipta terutama mengenai pembajakan dalam konteks Islam adalah dengan pidana pencurian atau Syaraqah. Untuk menentukan status hukum dari 
Jual Beli Produk Imitasi Fashion Perspektif Undang-Undang Hak Cipta Nomor 28 Tahun 2014 Dan Hukum Islam

Pembajakan dengan menyamakan hukum dari pencurian dapat menggunakan metode qiyas. Apabila dikaji berdasarkan metode qiyas, segala apapun bentuk dari pembajakan merupakan haram dan harus dijauhi. Dengan beberapa penjelasan di atas maka segala apapun bentuk pembajakan baik cara/metode maupun objek atau sasaran yang

\section{DAFTAR PUSTAKA}

As-Sa"dy. Abdurrahman Ibn Nasir, Risalah fi Al-Fiqh, Riyaz: Maktab Adhwa Salaf, 1998.

Butt Simon, dkk. 2013. Hak Kekayaan Intelektual Suatu Pengantar. Bandung: P.T. Alumn.

Damian, Edy. 2002. Hukum Hak Cipta. Bandung: PT. Alumni 2014.

Hak Kekayaan Intelektual. Cet.4. Bandung: PT. Alumni.

Djumhana, Muhammad. 2003. Hak Milik Intelektual (Sejarah, Teori dan Prakteknya di Indonesia). Bandung: PT. Citra Aditya Bakti.

Erman R dan Ridwan Khairandy. 1999. Teknologi dan alih Teknologi dalam Perspektif Hukum. Modul kuliah pasca sarjana magister hukum UII.

Fathoni, Abdurrahman. 2006. Metodologi Penelitian dan Tekhnik Penyusunan Skripsi. Jakarta: Rineka Cipta. Masduha, Abdurrahman. Pengantar Fiqh Muamallah.

Mifatahul, Huda, Syariah sosial: Etika Pranata Kultur, Mataram: IAIN

M.Ramli, Ahmad. Independen Dalam Perspektif Hukum Hak Cipta MATARAM, 2011.

Moleong, Lexy J. 2005. Metodologi Penelitian Kualitatif. Edisi Revisi. Cet.21. Bandung: Remaja Rosda Karya.

M. Quraish Shihab, 2008. Tafsir Al-Mishbah: Pesan, Kesandan Keserasian AlQur"an, Tangerang : Lentera Hati

Nurachmad,M. 2012. Segala Tentang Haki Indonesia. Cet 1. Jogjakarta: Buku Biru.

Purba, A dan G. Saleh. 2005. TRIPs-WTO\&Hukum HKI Indonesia. Jakarta: Rineka Cipta.

Riswandi, A. 2009. Hak Cipta Di Internet Aspek Hukum dan Permasalahnnya di Indonesia. Yogyakarta: FH UII Press.

Saidin, 2003. Aspek Hukum Kekayaan Intelektual. Jakarta : PT. Raja Grafindo Persada.

Sudargo, Gautama. Pembaharuan UUHC 1997. Bandung: Citra Aditya Bakti.

Sudaryat, S. 2010. Hak Kekayaan Intelektual (Memahami Prinsip Dasar, Cakupan, Dan Undang-Undang yang Berlaku). Cet 1. Bandung: Oase Media. Sugiyono, 2011. Metode Penelitian Kuantitatif Kualitatif Bandung : CV Alfabeta. Utomo, Suryo. Hak Kekayaan Intelektual, Suatu Pengantar: Bandung Mei 2006. 